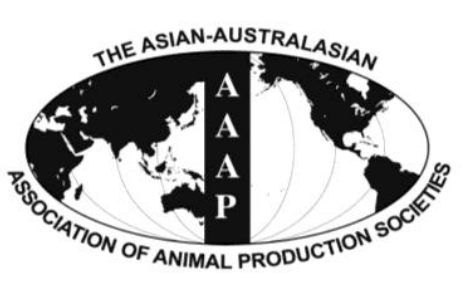

Open Access

Asian Australas. J. Anim. Sci.

Vol. 27, No. 6 : 880-885 June 2014

http://dx.doi.org/10.5713/ajas.2013.13646

www.ajas.info

pISSN 1011-2367 elSSN 1976-5517

\title{
Effect of Free-range Rearing on Meat Composition, Physical Properties and Sensory Evaluation in Taiwan Game Hens
}

\author{
Cheng-Yung Lin, Hsiao-Yun Kuo ${ }^{1}$, and Tien-Chun Wan ${ }^{2, *}$ \\ Kaohsiung Animal Propagation Station, COA-LRI, Kaohsiung, Taiwan
}

\begin{abstract}
Experiments were conducted to evaluate the effect of an outdoor-grazed raising model on meat composition, physical properties and sensory attributes of Taiwan game hens. Six hundred 1-d old female chicks were raised on a floor for 8 weeks. On day 57, 600 healthy birds, with similar body weight, were selected and randomly assigned to three treatment groups (cage, floor-pen and freerange). The results showed that different feeding models had no effect on drip loss, cooking loss, moisture, crude protein, crude fat, crude ash, zinc and calorie contents in breast meat and moisture content in thigh meat. The free-range group had the lowest fat content in both breast and thigh meat, and the lowest calorie content in thigh meat. The firmness and toughness in both thigh and breast of the freerange group were the highest values $(\mathrm{p}<0.05)$. The crude protein, total collagen, zinc and iron contents in thigh meat and total collagen content in breast meat of the free-range group were significantly higher than those of the cage-feeding group ( $<<0.05)$. The meat sensory scores of flavor, chewiness and overall acceptability of both thigh and breast meat of the free-range group were significantly ( $\mathrm{p}<0.05$ ) better than those of the other two groups. Moreover, the current findings also indicate that the Taiwan game hens of the free-range feeding model displayed well-received carcass traits and meat quality, with higher scores for flavor, chewiness and overall acceptability for greater sensory satisfaction in both breast and thigh meat. In addition, the thigh meat contained high protein and total collage but low fat, offering a healthier diet choice. (Key Words: Free-range, Meat Quality, Sensory Evaluation, Taiwan Game Hens)
\end{abstract}

\section{INTRODUCTION}

The so-called Taiwan native chickens represent a number of locally developed breeds favored by Taiwanese consumers. Taiwan game hens are one species of Taiwan native chickens and the main source of chicken meat in eastern Taiwan. Among different chicken species in the country, the unit price of the Taiwan game hens is the highest (Lin et al., 2009). It also accounted for nearly 1.5 percent of native chicken consumption (with 1,557 thousand birds slaughtered per year) or 3.5 percent of native chicken yield value (COA, 2012). In general, the rearing period to reach market weight for Taiwan game hens is

\footnotetext{
* Corresponding Author: Tien-Chun Wan. Tel: +886-6-5911211, Fax: +886-6-5912474, E-mail: tcwan52@kimo.com

${ }^{1}$ Physiology Division, COA-LRI, Hsinhua, Tainan, Taiwan.

${ }^{2}$ Animal Products Processing Division, COA-LRI, Hsinhua, Tainan, Taiwan.

Submitted Oct. 14, 2013; Revised Dec. 24, 2013; Accepted Jan. 2, 2014
}

longer (18 to 24 weeks) and the live weight of Taiwan game hens is also heavier ( 2.8 to $4.0 \mathrm{~kg}$ ), compared with Taiwan native chickens (Lin et al., 2009). Floor, cage and freerange feeding are the common models for meat-type chicken husbandry in Taiwan, but the Taiwan game hens are raised under free-range feeding. In ranching, free-range livestock are permitted to roam without fence, as opposed to fenced pastures (Bailey and Cosby, 2005). Castellini et al. (2002) also found that growth rates, feed efficiencies, gross energy and fat content in both breast and thigh meat of chickens reared with outdoor organic model were lower than those of with chickens reared conventional treatments. On the other hand, chickens reared with outdoor organic treatments had significantly higher sensory panel scores for juiciness and overall acceptability in breast meat. Outdoor organic treatment chickens had also higher percentages of breast and thigh meat, cooking loss and shear value. However, Cheng et al. (2008) found that the free-range chickens had a significantly higher percentage of breast, crude protein content, meat shear force values and

Copyright $@ 2014$ by Asian-Australasian Journal of Animal Sciences This is an open-access article distributed under the terms of the Creative Commons Attribution Non-Commercial License (http://creativecommons.org/licenses/by-nc/3.0/), which permits unrestricted non-commercial use, distribution, and reproduction in any medium, provided the original work is properly cited. 
chewiness, but significantly less crude fat content, meat L value, hardness and fracturability compared with conventional chickens. In Taiwan, consumers have traditionally preferred the meat obtained from free-range chickens to that from broilers, and are willing to pay a premium for free-range Taiwan native chickens. The aim of the study is to examine the effect of free-range rearing on meat composition, physical properties and sensory evaluation in Taiwan game hens compared with those reared by cage and floor feeding.

\section{MATERIALS AND METHODS}

\section{Animals, diets and experimental design}

Six hundred 0 -wk old Taiwan game hens were purchased from a breeding farm of Chang-Hua County and fed a conventional country chicken starter from 0 to 4 weeks (CP, 22\%; ME, 3,050 kcal/kg) and the grower diet from 5 to 8 weeks (CP, 19\%; ME, 3,000 kcal $/ \mathrm{kg}$ ). The game hens were fed on floor for 8 weeks, then divided into three groups according to weight in order to compare the cage, floor and free-range feeding models for a 12-week feeding experiment. The floor-pen rearing method was applied to a total of 200 chickens, with 40 chickens housed in each of the 5 pens and each pen measuring $2.5 \mathrm{~m} \times 4.0 \mathrm{~m}$ in size $(8$ birds $/ \mathrm{m}^{2}$ ). The cage-rearing method was applied to a total of
200 chickens allocated into pentaplicate (8 cages per replicate) with 5 birds in each cage and each cage measuring $90 \mathrm{~cm} \times 45 \mathrm{~cm} \times 50 \mathrm{~cm}$ in size $\left(12.3 \mathrm{birds} / \mathrm{m}^{2}\right)$. The free-range rearing method was applied to a total of 200 chickens allocated with 100 birds in each outdoor region $\left(10 \mathrm{~m} \times 20 \mathrm{~m}, 0.5\right.$ birds $\left./ \mathrm{m}^{2}\right)$, in which fences and netting were erected to keep out wild birds. Planted dwarf elephant grass (Napiergrass Taishu No. 3) grown by the Taiwan Livestock Research Institute was provided for forage and free intake by chickens. One fifth of the area $(4 \mathrm{~m} \times 4 \mathrm{~m})$ was used as a shelter with perches. Water and feed were provided in four regions for rotational grazing of chickens, each region for three weeks. All chickens were provided with the same starter, grower and finisher diets and raised according to the feeding schedule as reported by Lin et al. (2008). Details of diet formulations, compositional analyses and feeding schedules are summarized in Table 1. The birds received natural light. Feed and water were provided and feeding was ad libitum.

\section{Sample collection and analysis}

Sample chickens, each group contained 24 sample chickens at 20 weeks of age after $24 \mathrm{~h}$ of feed deprivation, were weighed and sacrificed using standard procedures, as reported by Koch and Possa (1973). Weights of evisceration, abdominal fat, thigh and breast meat were obtained for each

Table 1. Composition of the experimental diet

\begin{tabular}{|c|c|c|c|c|c|}
\hline \multirow{2}{*}{ Ingredients $(\%)$} & \multicolumn{5}{|c|}{ Feeding schedule and age (in weeks) } \\
\hline & $0-4$ & $5-8$ & $9-12$ & $13-16$ & $17-20$ \\
\hline Yellow corn & 53.02 & 63.95 & 64.08 & 67.3 & 69.1 \\
\hline Wheat bran & 0.0 & 0.0 & 8.5 & 14.0 & 15.0 \\
\hline Soybean meal (44.0\%) & 36.7 & 30.2 & 24.5 & 16.0 & 13.0 \\
\hline Fish meal $(65 \%)$ & 3.0 & 1.5 & 0.0 & 0.0 & 0.0 \\
\hline Dicalcium phosphate & 1.0 & 1.0 & 0.85 & 0.8 & 0.8 \\
\hline Limestone, pulverized & 1.5 & 1.5 & 1.43 & 1.3 & 1.5 \\
\hline Soybean oil & 4.0 & 1.2 & 0.0 & 0.0 & 0.0 \\
\hline Salt & 0.5 & 0.4 & 0.4 & 0.4 & 0.4 \\
\hline Premix $^{1}$ & 0.2 & 0.2 & 0.2 & 0.2 & 0.2 \\
\hline Methionine & 0.08 & 0.05 & 0.04 & 0.0 & 0.0 \\
\hline \multicolumn{6}{|l|}{ Calculated value (\%) } \\
\hline Metabolizable energy $(\mathrm{kcal} / \mathrm{kg})$ & 3,061 & 3,005 & 2,918 & 2,965 & 2,981 \\
\hline Crude protein & 22.3 & 19.0 & 17.1 & 14.4 & 13.4 \\
\hline Calcium & 1.02 & 0.95 & 0.83 & 0.75 & 0.82 \\
\hline Total phosphorus & 0.62 & 0.57 & 0.57 & 0.58 & 0.57 \\
\hline Available phosphorus & 0.42 & 0.37 & 0.32 & 0.31 & 0.31 \\
\hline Crude fiber & 3.21 & 3.5 & 3.97 & 4.01 & 3.93 \\
\hline Lysine & 1.28 & 1.05 & 0.88 & 0.69 & 0.62 \\
\hline Methionine & 0.44 & 0.37 & 0.32 & 0.25 & 0.24 \\
\hline Methionine+cystine & 0.80 & 0.70 & 0.63 & 0.52 & 0.50 \\
\hline
\end{tabular}

${ }^{1}$ Supplied per kilogram of diet: vitamin $\mathrm{A}, 100,000 \mathrm{IU}$; vitamin $\mathrm{D}_{3}$, 20,000 IU; vitamin $\mathrm{E}, 15 \mathrm{mg}$; vitamin $\mathrm{K}_{3}, 4 \mathrm{mg}$; vitamin $\mathrm{B}_{1}, 2 \mathrm{mg}$; Vitamin $\mathrm{B}_{2}$, $6 \mathrm{mg}$; Vitamin $B_{6}, 4$ mg; Vitamin $B_{12}, 0.02$ mg; Niacin, 40 mg; Pantothenic acid, 12 mg; Folic acid, 1 mg; Fe, 80 mg; Cu, 10 mg; Mn,55 mg; Zn, 45 mg; I, 0.3 $\mathrm{mg} ; \mathrm{Se}, 0.1 \mathrm{mg}$. 
chicken prior to the processing procedure. Dressed weight is equal to the eviscerated weight. Dressing and abdominal fat as a percentage of body mass was measured according to the fasting weight of the live birds. Carcass parts as a percentage of the body mass were measured according to the eviscerated weight.

The samples were collected from the breast and thigh meat of the carcasses. The meat was obtained $2 \mathrm{~h}$ after slaughter in a chilled room, packed in low-density polyethylene bags (LDPE) manufactured by Peichengplast Co., Tainan, Taiwan and kept at $4 \pm 1^{\circ} \mathrm{C}$ for about $24 \mathrm{~h}$. Then, the fat and connective tissue were removed and the meat samples were portioned, packed in LDPE bags and transferred to a freezer maintained at $-20 \pm 1^{\circ} \mathrm{C}$ until analysis. The meat samples were thawed at $4 \pm 1^{\circ} \mathrm{C}$ for $12 \mathrm{~h}$ before analysis and ground in a mincer, packed in LDPE bags and stored in a refrigerator $\left(4 \pm 1^{\circ} \mathrm{C}\right)$ until required.

Moisture, crude fat, crude protein and crude ash were determined according to the method of AOAC (2000). The moisture content was determined by oven drying; crude protein by Kjeldahl nitrogen estimation; and crude fat by Soxhlet extraction with petroleum ether. The amount of total collagen was determined according to the method described by Hill (1966). Calories were calculated by multiplying the raw amount of each input of the energy intensity factor. The contents of zinc $(\mathrm{Zn})$ and iron $(\mathrm{Fe})$ were measured according to the method of AOAC (2000). Briefly, meat samples $(2 \mathrm{~g})$ were homogenized with $4 \mathrm{~mL}$ of concentrated nitric acid and were heated using a hot plate until complete digestion. The digested samples were transferred to a volumetric flask and the volume was adjusted to $10 \mathrm{~mL}$ with deionized water. Minerals were measured in the solution by atomic absorption spectroscopy. The concentration of minerals was calculated and expressed as $\mathrm{mg} / \mathrm{kg}$ (ppm) samples.

Drip loss was determined according to the bag method of Honikel (1998). Briefly, meat samples about $2.5 \mathrm{~cm}$ thick were removed from the breast (Pectoralis major) and thigh (Gastrocnemius pars extrna.) meat of each chicken. Samples were suspended by string in an expanded bag. The samples were then suspended at $4^{\circ} \mathrm{C}$ for $48 \mathrm{~h}$, at which time the surface was lightly blotted with a paper tissue and reweighed. Drip loss was then expressed as a percentage of the original weight of the steak. The meat samples used for physical evaluation were cooked in a plastic bag in a water bath at $85^{\circ} \mathrm{C}$ until they reached an internal temperature of $70^{\circ} \mathrm{C}$ (about $25 \mathrm{~min}$ ). Cooking loss was measured for breast and thigh meat as reported by Florene et al. (1994). Cooking loss was determined by recording uncooked and cooked weights of the breast and thigh meat. Meat samples for mechanical assessment of toughness and hardness were cooled to $20^{\circ} \mathrm{C}$ and were cut into $2 \times 1 \times 1 \mathrm{~cm}$ cubes parallel to the longitudinal orientation of the muscle fibers for Texture Analyser (TA.XT-Plus, Stable Micro Systems, UK) measurement. The crosshead speed was $5 \mathrm{~mm} / \mathrm{s}$. Results were expressed as maximum shearing force $/ \mathrm{kg}$, as reported by Lyon and Lyon (1996).

The breast and thigh meat of six chickens from each treatment were thawed for $12 \mathrm{~h}$ at 0 to $4^{\circ} \mathrm{C}$. Then samples were used for sensory evaluation. The samples were insulated with aluminum foil, placed in a water batch, and preheated to $85^{\circ} \mathrm{C}$. The samples remained in the water bath until an internal temperature of approximately $80^{\circ} \mathrm{C}$ was obtained. This process usually took 20 to $30 \mathrm{~min}$. After being cooked, the breast and thigh meat were immediately cut into one-half inch cubes, placed in warm, white, opaque containers and served to a taste panel of 17 trained panellists (staff of the Livestock Research Institute, Taiwan).

Each panel member received one cube of breast muscle and one cube of thigh meat from each cooked half chicken. Meat samples were scored for flavor, juiciness, chewiness and overall acceptability using a seven-point hedonic scale (with 1-very undesirable, 7-very desirable).

\section{Statistical analysis}

The following items were statistically analyzed: meat composition, physical properties and sensory evaluation indices. The association between items and different models was analyzed. Data collected were subjected to analysis of variance using the General Linear Models (GLM) procedure of SAS (SAS Institute Inc., Cary, NC, USA). When significant $(\mathrm{p}<0.05)$ differences were detected, means were separated using Least Squares Means (LSMeans). Characteristics with $\mathrm{p}<0.05$ were discussed as trends.

\section{RESULTS AND DISCUSSION}

\section{Meat composition}

The results of thigh and breast meat composition obtained in this study are displayed in Table 2. The crude fat content in both the breast and thigh meat, and calorie content in thigh meat of the cage group were significantly higher $(p<0.05)$ than those of the free-range group, while the free-range group had significantly higher $(\mathrm{p}<0.05)$ contents of crude protein, iron, zinc and total collagen in thigh meat and higher contents of total collagen in breast meat. However, the contents of moisture, crude protein, crude ash, zinc and calorie in breast meat and moisture contents in thigh meat showed no significant difference among groups. These finding were consistent with the results from Fanatico et al. (2005a) and Wang et al. (2009), who showed no difference in nutrient composition (water, crude protein and crude fat) of breast meat among different raising systems. Similarly, Cheng et al. (2008) also reported that free-range chickens had higher protein content of thigh 
Table 2. Meat composition of Taiwan game hen in different feeding models

\begin{tabular}{|c|c|c|c|c|}
\hline Items & Cage & Floor & Free-range & p-value \\
\hline \multicolumn{5}{|l|}{ Thigh } \\
\hline Moisture (\%) & $75.3 \pm 1.4$ & $75.4 \pm 1.3$ & $75.7 \pm 1.2$ & $>0.05$ \\
\hline Crude protein $(\%)$ & $21.7 \pm 1.1^{\mathrm{b}}$ & $22.3 \pm 1.2^{\mathrm{a}}$ & $22.3 \pm 1.1^{\mathrm{a}}$ & $<0.05$ \\
\hline Crude fat $(\%)$ & $2.24 \pm 0.85^{\mathrm{a}}$ & $2.19 \pm 0.88^{\mathrm{a}}$ & $1.65 \pm 0.82^{\mathrm{b}}$ & $<0.05$ \\
\hline Crude ash $(\%)$ & $1.06 \pm 0.15^{\mathrm{a}}$ & $1.02 \pm 0.18^{\mathrm{b}}$ & $1.04 \pm 0.19^{\mathrm{ab}}$ & $<0.05$ \\
\hline $\mathrm{Fe}, \mathrm{ppm}$ & $12.80 \pm 4.15^{\mathrm{b}}$ & $17.72 \pm 4.08^{\mathrm{a}}$ & $14.51 \pm 3.97^{\mathrm{a}}$ & $<0.05$ \\
\hline $\mathrm{Zn}, \mathrm{ppm}$ & $22.60 \pm 3.40^{\mathrm{b}}$ & $24.40 \pm 3.36^{\mathrm{ab}}$ & $25.75 \pm 3.28^{\mathrm{a}}$ & $<0.05$ \\
\hline Calorie (kcal/100 g) & $138.0 \pm 7.9^{\mathrm{a}}$ & $139.0 \pm 7.6^{\mathrm{a}}$ & $134.7 \pm 7.2^{\mathrm{b}}$ & $<0.05$ \\
\hline Total collagen $(\mathrm{mg} / \mathrm{g})$ & $8.86 \pm 0.78^{\mathrm{a}}$ & $7.07 \pm 0.67^{b}$ & $9.82 \pm 0.72^{\mathrm{a}}$ & $<0.05$ \\
\hline \multicolumn{5}{|l|}{ Breast } \\
\hline Moisture (\%) & $72.5 \pm 1.1$ & $72.4 \pm 1.0$ & $72.8 \pm 0.9$ & $>0.05$ \\
\hline Crude protein $(\%)$ & $25.3 \pm 0.7$ & $25.7 \pm 0.6$ & $25.5 \pm 0.5$ & $>0.05$ \\
\hline Crude fat $(\%)$ & $0.51 \pm 0.34^{\mathrm{a}}$ & $0.44 \pm 0.23^{\mathrm{a}}$ & $0.25 \pm 0.32^{\mathrm{b}}$ & $<0.05$ \\
\hline Crude ash (\%) & $1.50 \pm 0.22$ & $1.41 \pm 0.13$ & $1.69 \pm 0.12$ & $>0.05$ \\
\hline $\mathrm{Fe}(\mathrm{ppm})$ & $11.07 \pm 3.15^{\mathrm{ab}}$ & $8.52 \pm 2.95^{\mathrm{b}}$ & $12.58 \pm 3.03^{\mathrm{a}}$ & $<0.05$ \\
\hline $\mathrm{Zn}(\mathrm{ppm})$ & $7.23 \pm 2.70$ & $6.44 \pm 3.21$ & $7.98 \pm 2.52$ & $>0.05$ \\
\hline Calorie (kcal/100 g) & $146.7 \pm 5.5$ & $146.5 \pm 5.8$ & $144.9 \pm 5.2$ & $>0.05$ \\
\hline Total collagen $(\mathrm{mg} / \mathrm{g})$ & $2.45 \pm 0.30^{\mathrm{b}}$ & $2.90 \pm 0.32^{\mathrm{ab}}$ & $3.25 \pm 0.28^{\mathrm{a}}$ & $>0.05$ \\
\hline
\end{tabular}

$\overline{\mathrm{a}, \mathrm{b}}$ Means in the same row without the same superscript are significantly different $(\mathrm{p}<0.05)$.

and breast meat whereas conventional raised chickens had higher fat content of thigh and breast meat. Moreover, Castellini et al. (2002) found that the gross energy and crude fat content in both breast and thigh meat were significantly lower in chickens raised with outdoor organic treatments than those reared under conventional treatments. These differences were attributed to increased physical activity of chickens raised with outdoor organic treatments that favored myogenesis over lipogenesis. Moreover, enhancement in the total collagen content in both breast and thigh meat of the free-range group is probably due to increased exercise leading to high amount of connective tissue. Collagen is an abundant connective tissue protein as reported by Weston et al. (2002). Collagen is also the most important stress-carrying protein component in muscle and skeleton. The tissue collagen provides muscle and bone the great tensile strength and hard rigid properties (Yang et al., 2014).

Therefore, it is reasonable to expect that the free-range group had higher contents of zinc and iron in thigh meat, which was associated with free intake of stone and forage, compared with the other groups. Furthermore, in this study, thigh and breast meat of free-range chickens had higher $(p<0.05)$ iron content, which could be attributed to increased myoglobin content, and this may also be attributed to increased physical activity associated with access to the outdoors as discussed by Husak et al. (2008).

Table 3 summarizes the physical properties of meat from the chickens in the study. The drip loss and cooking loss of thigh and breast meat did not differ significantly among the three experimental groups $(p>0.05)$. The freerange group had the highest firmness and toughness in both

Table 3. Physical properties of Taiwan game hen in different feeding models

\begin{tabular}{|c|c|c|c|c|}
\hline Items & Cage & Floor & Free-range & p-value \\
\hline \multicolumn{5}{|l|}{ Thigh } \\
\hline Drip loss (\%) & $0.99 \pm 0.11$ & $1.51 \pm 0.13$ & $2.48 \pm 0.15$ & $>0.05$ \\
\hline Cooking loss $(\%)$ & $26.6 \pm 0.62^{\mathrm{a}}$ & $24.8 \pm 0.60^{\mathrm{b}}$ & $26.8 \pm 0.64^{\mathrm{ab}}$ & $<0.05$ \\
\hline Firmness (kg) & $4.49 \pm 0.25^{\mathrm{ab}}$ & $4.22 \pm 0.27^{\mathrm{b}}$ & $5.99 \pm 0.29^{\mathrm{a}}$ & $<0.05$ \\
\hline Toughness (kg) & $22.6 \pm 0.51^{\mathrm{b}}$ & $13.2 \pm 0.47^{\mathrm{c}}$ & $35.3 \pm 0.55^{\mathrm{a}}$ & $<0.05$ \\
\hline Breast & $5.91 \pm 0.46$ & $4.48 \pm 0.44$ & $6.17 \pm 0.48$ & $>0.05$ \\
\hline \multicolumn{5}{|l|}{ Drip loss (\%) } \\
\hline Cooking loss (\%) & $18.4 \pm 0.72$ & $16.7 \pm 0.75$ & $17.2 \pm 0.78$ & $>0.05$ \\
\hline Firmness (kg) & $3.14 \pm 0.25^{\mathrm{b}}$ & $3.42 \pm 0.28^{\mathrm{b}}$ & $4.64 \pm 0.31^{\mathrm{a}}$ & $<0.05$ \\
\hline Toughness (kg) & $6.88 \pm 0.69^{\mathrm{b}}$ & $6.99 \pm 0.71^{\mathrm{ab}}$ & $9.08 \pm 0.67^{\mathrm{a}}$ & $<0.05$ \\
\hline
\end{tabular}

\footnotetext{
$\overline{a, b, c}$ Means in the same row without the same superscript are significantly different $(\mathrm{p}<0.05)$.
} 
thigh and breast meat $(\mathrm{p}<0.05)$. This is in agreement with reports by Cheng et al. (2008) who showed no difference in water holding capacity and purge loss in both breast and leg meat between the free-range rearing group and the conventional raising group. However, the free-range rearing group had significantly greater shear force and chewiness than the conventional raising group. Similar results have been reported by Farmer et al. (1997) that broilers reared in low stocking density exhibited higher shear values in either breast or thigh meat, presumably as a consequence of their greater motor activity. Nevertheless, it contradicted the result reported by Castellini et al. (2002) that cooking loss in chickens raised with outdoor organic treatment was higher than that in chickens reared with conventional treatment, due to their greater motor activity or increased physical activity. Therefore, it is reasonable to expect that free-range birds had greater firmness and toughness in both breast and thigh meat, which was associated with higher collagen content in both breast and thigh meat, compared with the other groups. Collagen, an abundant connective tissue protein, contributes to variations in meat tenderness and texture. It is associated with background toughness and can be quite resistant to physical breakdown during cooking (Weston et al., 2002). However, McCormick (1999) concluded that collagen concentration and mature crosslinks have an additive effect on toughness of meat.

\section{Sensory evaluation}

The taste panel scores of breast and thigh meat are shown in Table 4. As can be seen, the free-range group produced significantly $(\mathrm{p}<0.05)$ higher taste panel scores than the other groups. Thigh meat of the free-range group had high scores in flavor, juiciness, chewiness and overall acceptability, while their breast meat also had high scores in flavor, chewiness and overall acceptability. However, there was no differences in score of juiciness in breast meat among the cage, floor and free-range groups. Similarly, Castellini et al. (2002) found significantly higher taste panel scores for juiciness and overall acceptability of breast meat for the organic rearing chickens than for the conventional rearing chickens. Moreover, Cheng et al. (2008) reported that there were no significant differences in aroma, flavor, firmness, tenderness, juiciness and overall acceptability between free-range and conventional treatments. Furthermore, Farmer et al. (1977) reported that stocking density had less effect on the eating quality attributes of chicken compared with genotype or diet, but the low stocking density birds showed an increase in odor intensity in thigh meat than high stocking density birds, which is probably due to additional exercise leading to increase in formation of odor compounds.

In contrast, Husak et al. (2008) indicated that breast and thigh meat of conventional reared chickens was tender and less chewiness when compared with that of free range and organic broilers, but there were no significant differences in aroma, flavor, juiciness and tenderness among attributes of breast and thigh meat among chickens reared by different methods. However, Cheng et al. (2008) showed that breast and thigh meat of free-range chickens had significantly higher shear force and chewiness, but markedly lowered hardness and fracturability, compared with conventionally reared chickens. On the other hand, the higher taste panel scores of both breast and thigh meat in free-range chickens are probably due to increased physical activity leading to increased collagen content of meat. Collagen is the connective tissue contributing to less tender meat, as elastin and reticulin are found in much smaller amounts and do not appear to contribute to unfavorable tenderness (Bailey, 1972). Collagen is also associated with background toughness and can be quite resistant to physical breakdown during cooking (Marsh, 1997). However, McCormick (1999) indicated that collagen concentration and mature crosslinks have an additive effect on the toughness of meat. Many factors including diet, age, genotype, pre-slaughter handling, post-slaughter chilling and meat contents affect meat sensory scores. It is difficult to conclusively assess the role of organic, free-range and conventional production systems alone on meat sensory scores.

Table 4. Sensory evaluation of Taiwan game hen in different feeding models

\begin{tabular}{|c|c|c|c|c|}
\hline Items & Cage & Floor & Free-range & p-value \\
\hline \multicolumn{5}{|l|}{ Breast } \\
\hline Flavor & $4.67 \pm 0.94^{\mathrm{b}}$ & $5.00 \pm 1.04^{\mathrm{a}}$ & $5.05 \pm 0.93^{\mathrm{a}}$ & $<0.05$ \\
\hline Chewiness & $4.90 \pm 1.07^{\mathrm{b}}$ & $4.86 \pm 1.10^{\mathrm{b}}$ & $5.17 \pm 0.92^{\mathrm{a}}$ & $<0.05$ \\
\hline Juiciness & $4.86 \pm 1.05$ & $4.91 \pm 1.10$ & $5.07 \pm 1.01$ & $>0.05$ \\
\hline Overall acceptability & $4.83 \pm 1.08^{\mathrm{ab}}$ & $4.95 \pm 1.07^{\mathrm{b}}$ & $5.19 \pm 0.93^{\mathrm{a}}$ & $<0.05$ \\
\hline \multicolumn{5}{|l|}{ Thigh } \\
\hline Flavor & $4.91 \pm 0.97^{\mathrm{b}}$ & $4.75 \pm 0.90^{\mathrm{b}}$ & $5.17 \pm 1.06^{\mathrm{a}}$ & $<0.05$ \\
\hline Chewiness & $5.09 \pm 1.06^{\mathrm{b}}$ & $4.94 \pm 0.99^{\mathrm{b}}$ & $5.35 \pm 0.93^{\mathrm{a}}$ & $<0.05$ \\
\hline Juiciness & $4.83 \pm 1.09^{\mathrm{b}}$ & $4.83 \pm 1.01^{\mathrm{b}}$ & $5.19 \pm 1.03^{\mathrm{a}}$ & $<0.05$ \\
\hline Overall acceptability & $4.89 \pm 1.07^{\mathrm{ab}}$ & $4.81 \pm 1.00^{\mathrm{b}}$ & $5.13 \pm 1.06^{\mathrm{a}}$ & $<0.05$ \\
\hline
\end{tabular}

\footnotetext{
$\overline{a, b, c}$ Means in the same row without the same superscript are significantly different $(\mathrm{p}<0.05)$.
} 


\section{CONCLUSION}

In summary, free-range Taiwan game hens had the best results of sensory evaluation and were well received by the sensory panel or panelists. Both breast and thigh meat of free-range Taiwan game hens offered better sensory satisfaction and for a healthier diet choice. Free-range game hens had lower crude fat, higher collagen, crude protein contents and better texture for chewiness.

\section{ACKNOWLEDGEMENTS}

This work was supported by the Council of Agriculture, Executive Yuan, ROC.

Contribution No. 1906 from Livestock Research Institute (LRI), Council of Agriculture (COA), Executive Yuan, Taiwan.

\section{REFERENCES}

AOAC (Association of Official Analytical Chemists). 2000. Official Methods of Analysis of the Association of Official Analytical Chemists. 17th ed. National Academy Press, Washington, DC.

Bailey, A. J. 1972. The basis of meat texture. J. Sci. Food Agric. 23:995-1007.

Bailey, J. S. and D. E. Cosby. 2005. Salmonella prevalence in freerange and certified organic chickens. J. Food Prot. 68:24512453.

Castellini, C., C. Mugnai, and A. Dal Bosco. 2002. Effect of organic production system on broiler carcass and meat quality. Meat Sci. 60:219-225.

Cheng, F. Y., C. W. Huang, T. C. Wan, Y. T. Liu, L. C. Lin, and C. Y. Lou Chyr. 2008. Effect of free-range farming on carcass and meat qualities of black-feathered Taiwan native chicken. Asian Australas. J. Anim. Sci. 21:1201-1206.

COA. 2012. Agriculture Year Book. Council of Agriculture, Executive Yuen, Taipei, Taiwan.

Fanatico, A. C., L. C. Cavitt, P. B. Pillai, J. L. Emmert, and C. M. Owens. 2005. Evaluation of slow-growing broiler genotypes grown with and without outdoor access: Meat quality. Poult. Sci. 84:1785-1790.
Farmer, L. J., G. C. Perry, P. D. Lewis, G. R. Nute, J. R. Piggott, and R. L. S. Patterson. 1997. Responses of two genotypes of chicken to the diets and stocking densities of conventional UK and label rouge production system. II. Sensory attributes. Meat Sci. 47:77-93.

Florene, G., C. Touraille, A. Oual, M. Renerre, and G. Moni. 1994. Relationships between postmortem $\mathrm{pH}$ changes and some traits of sensory quality in veal. Meat Sci. 37:315-325.

Hill, F. 1966. The solubility of intramuscular collagen in meat animals of various ages. J. Food Sci. 31:161-166.

Honikel, K. O. 1998. Reference methods for the assessment of physical characteristics of meat. Meat Sci. 49:447-457.

Husak, R. L., J. G. Sebranek, and K. Bregendahl. 2008. A survey of commercially available broilers marketed as organic, freerange, and conventional broilers for cooked meat yields, meat composition, and relative value. Poult. Sci. 87:2367-2376.

Koch, T. and E. Possa. 1973. Anatomy of the Chicken and Domestic Birds. Humboldt University, West Germany. p. 12.

Lin, C. Y., M. L. Lee, and H. Y. Kuo. 2008. Comparison between five and three phase feeding program of Taiwan game hens. J. Chin. Soc. Anim. Sci. 37(Suppl.):270.

Lin, C. Y., M. L. Lee, H. Y. Kuo, and M. S. Duh. 2009. A study on the optimal marketing age of Taiwan game hens. J. Taiwan Livest. Res. 42:35-45. (in Chinese).

Lyon, B. G. and C. E. Lyon. 1996. Texture evaluations of cooked, diced broiler breast samples by sensory and mechanical methods. Poult. Sci. 75:812-819.

Marsh, B. B. 1977. The nature of tenderness. In Proc. 30th Annu. Recip. Meat Conf. 30:69.

McCormick, R. J. 1999. Extracellular modifications to muscle collagen: Implications for meat quality. Poult. Sci. 78:785-791.

SAS. (Statistical Analysis Software). 2006. The SAS system for Windows (Release 9.1). SAS Inst. Inc, Cary, NC, USA.

Wang, K. H., S. R. Shi, T. C. Dou, and H. J. Sun. 2009. Effect of a free-range raising system on growth performance, carcass yield, and meat quality of slow-growing chicken. Poult. Sci. 88:2219-2223.

Weston, A. R., R. W. Rogers, and T. G. Althen. 2002. Review: The role of collagen in meat tenderness. Prof. Anim. Sci. 18:107111 .

Yang, W., X. Xi, Q. Ran, P. Liu, Y. Hu, and K. Cai. 2014. Influence of the titania nanotubes dimensions on adsorption of collagen: An experimental and computational study. Mater. Sci. Eng. C 34:410-416. 